Video education

\section{US engineers forge ahead}

\section{Washington}

The poor track record of video-based education in the United States is showing signs of improvement. Mid-career engineers employed in US companies are now benefiting from the country's first widely successful experiment in video education.

Orders have been mushrooming for engineering and related courses to be taught by video this year and compiled and catalogued by a little-known group based in Atlanta, Georgia. Although the Association for Media-Based Continuing Education (AMCEE) is only two months into its current fiscal year, it has as many orders now as it had halfway through the previous year. John T. Fitch, the group's executive director, estimates that some 30,000 to 40,000 people, most of them engineers although they include businessmen and secretaries, are taking AMCEE-offered courses.

AMCEE serves as a nonprofit-making clearinghouse for courses produced at universities around the country. Its member universities now number 22 and include many state institutions and private schools.

To qualify, a school must have a campus-based media-based continuing education programme. The programme films the professor lecturing to students or in a campus studio - packages the cassettes and related text material, and distributes them, weekly or biweekly, to companies, usually in the immediate area. This year's AMCEE catalogue contains 448 courses in 18 disciplines given at 21 universities. Course contents range from "Grammar for Secretaries" to "Advanced Heat Flow Analysis".

The latter course, taught by Professor W. Edwards Deming of Massachusetts Institute of Technology and consisting of 14 videocassettes and a textbook, has been a best-seller. In it, Deming teaches, according to the AMCEE catalogue, why "productivity increases as quality improves" in industrial production, and explains the " 14 steps that must be adapted to achieve this result"'. There have been at least 4,000 orders for this course.

Some of the participating schools have raised continuing education for engineers by video to an advanced art. Colorado State University, for example, offers 76 video courses, most taken by students who are employed at companies in the DenverBoulder area. Couriers drive the taped cassettes around to the locations where the students are taking the courses - usually at their employers' offices - and pick up homework assignments, questions, and the like.
AMCEE's success - which is in marked contrast to many other attempts at systematized video learning for credit - is based, says Fitch, on a tradition in engineering that calls for working engineers to go back to school, to catch up on basic knowledge that has advanced since they graduated, or to retrain for new specialities. Traditionally, companies give their employees leave to go back to school for this retraining, but this is expensive in terms of lost pay, commuting costs, and tuition. The video system means that the engineer can take the course at his office, while remaining employed.

So far, AMCEE does not offer any courses for undergraduate engineers. However, it does have big plans. Under Dr Lionel Baldwin, dean of engineering at Colorado State University, AMCEE is drawing up plans for schools to offer courses by satellite in real time, so that the engineer who has moved with his job to Massachusetts can take a course offered at Stanford and talk to his teacher by satellite. The proposed "National Technical University" could offer an accredited degree - all by video.

If the plan materializes, it will be a big step for AMCEE, which was embryonic after its founding in 1976 until grants from the National Science Foundation and the Alfred P. Sloan Foundation helped it get started gathering and vetting course materials.

Although a study by the Corporation for Public Broadcasting published last year estimated that half a million people around

the United States take some kind of course using television, specific programmes of video education have not usually fared well. At the end of this month, for example, the University of Mid-America (UMA) goes out of business; it was an

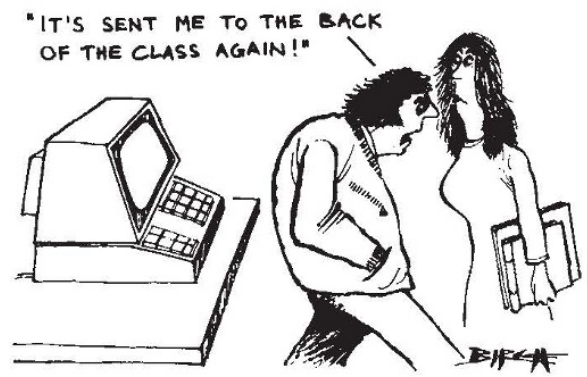

eight-year attempt, funded by the federal government and supported by 11 state universities, to make and distribute video courses around the mid-west. At present, says Milan Wall of UMA, around 8,000 students take courses that use UMAdeveloped materials, which range from a history of the Great Plains to subjects in the humanities. But UMA's market housewives seeking more learning and adults who dropped out of college but who now want to complete their degrees - has not materialized. Even direct distribution of British Open University programmes has not been extensive, Wall says, "not because they're not of high quality but because they're designed for a totally different educational system."

Deborah Shapley

\title{
China's intellectuals back in fashion
}

China's new policy of eliminating traces of "leftism" which led to the recent abolition of the post of Party Chairman, will mean an upgrading of both status and living standards for intellectuals. A number of party and government documents, mostly at provincial level, have recently called for educational campaigns, intended to "surmount the traditional stance of looking down on intellectuals".

Proposed measures include:

- The complete rehabilitation of all intellectuals unjustly or falsely persecuted during the cultural revolution, including the restoration of or compensation for lost salaries, and the "education" of those involved in the "mishandling" of such cases.

Opportunities for employment for intellectuals in accordance with their talents and qualifications. Intellectuals with "ability and integrity" who are in the "prime of life" should be selected for key posts, and their opinions on economic policy listened to "conscientiously". Party cadres are instructed to respect non-party intellectuals, while factories and other organizations assigned new graduates "must not haggle" about giving them

\section{appropriate employment.}

- Intellectuals should be able to spend five sixths of their working time on professional activity; facilities (including study leave) must be provided for them to keep up their knowledge.

- The system of examinations and promotions for professional and technical grades and titles should be improved. Allowances for education and research in provincial budgets should be gradually increased and the provision of equipment, instruments, books and auxiliary staff ensured. Party schools should offer scientific and technical courses. Administrators in key posts whose own academic or technical background is not up to standard should be sent on refresher courses.

Some officials, it is noted, have not recognized the importance of intellectuals in the community, considering that once the intellectuals in their particular area have been rehabilitated, all is well. Parents, however, have been quick to grasp the new trend and a recent article in the party journal Red Flag criticizes parents who have already started cramming their three- and fouryear old children in preparation for university entrance.
Vera Rich 